\title{
Hubungan Pemahaman tentang Surat-Menyurat terhadap Kemampuan Menulis Surat Dinas Siswa Kelas VII SMP Negeri 9 Oku
}

\author{
Awalludin $^{* 1}$, M. Rama Sanjaya ${ }^{2}$, Asmi Bataria ${ }^{3}$ \\ Universitas Baturaja \\ Email: awalludinawri@gmail.com ${ }^{1}$, sanjayamuhamadrama@gmail.com², \\ asmibataria@gmail.com ${ }^{3}$ \\ Corresponding email: awalludinawri@gmail.com*1
}

\begin{abstract}
The ability to write student official letters is predicted to be influenced by an initial understanding of the material of the correspondence. For this reason, this study aims to: (1) find out the understanding of correspondence for Grade VII students of OKU 9 Public Middle School, (2) to determine the ability to write official letters for VII grade students of SMP Negeri 9 OKU, and (3) to find out the relationship between understanding of correspondence to the ability of Grade VII students of SMP Negeri $9 \mathrm{OKU}$ to write official letters. The method used in this research is correlation method. The data collection technique used is a test. Data analysis technique used is descriptive statistical analysis techniques. Test results Based on the calculation of the correlation between the test data understanding correspondence with the ability to write official letter VII grade students of SMP Negeri 9 OKU obtained the value of $r$ product moment at a significant level of $5 \%$ of 0.381 with $r_{x y}$ of 0.987 . When compared to $r$ arithmetic $\left(r_{x y}\right)$, then $r_{x y}$ is greater $r$ product moment. That is, the alternative hypothesis $(\mathrm{Ha})$ is accepted and the null hypothesis (Ho) is rejected. Thus, it can be concluded that there is a significant relationship between the understanding of correspondence with the ability to write official letters for eighth grade students of SMP Negeri 9 OKU.
\end{abstract}

Keywords: relationships, understanding, correspondence, writing, official letter

\begin{abstract}
Abstrak
Kemampuan menulis surat dinas siswa diprediksi dipengaruhi oleh pemahaman awal tentang materi surat-menyurat. Untuk itu, penelitian ini bertujuan untuk: (1) untuk mengetahui pemahaman tentang surat menyurat siswa kelas VII SMP Negeri 9 OKU, (2) untuk mengetahui kemampuan menulis surat dinas siswa kelas VII SMP Negeri 9 OKU, dan (3) untuk mengetahui hubungan antara pemahaman tentang surat-menyurat terhadap kemampuan siswa kelas VII SMP Negeri 9 OKU menulis surat dinas. Metode yang digunakan dalam penelitian ini adalah metode korelasi. Teknik pengumpulan data yang digunakan adalah tes. Tenik analisis data yang digunakan adalah teknik analisis statistik deskriptif. Hasil tes berdasarkan perhitungan korelasi antara data tes pemahaman surat menyurat dengan kemampuan menulis surat dinas siswa kelas VII SMP Negeri 9 OKU diperoleh nilai $r$ product moment pada taraf signifikan $5 \%$ sebesar 0,381 dengan $r_{x y}$ sebesar 0,987 . Jika dibandingkan dengan $r$ hitung $\left(r_{x y}\right)$, maka $r_{x y}$ lebih besar $r$ product moment. Artinya, hipotesis alternatif $(\mathrm{Ha})$ diterima dan hipotesis nihil $(\mathrm{Ho})$ ditolak. Dengan demikian, dapat disimpulkan bahwa ada hubungan
\end{abstract}


yang signifikan antara pemahaman surat menyurat dengan kemampuan menulis surat dinas siswa kelas VII SMP Negeri 9 OKU.

Kata kunci: hubungan, pemahaman tentang surat-menyurat, kemampuan menulis surat dinas

\section{PENDAHULUAN}

Bahasa adalah sarana komunikasi yang mutlak diperlukan oleh semua anggota masyarakat karena dengan bahasa seseorang dapat mengutarakan baik pikiran, gagasan maupun isi hatinya kepada orang lain. Bahasa merupakan alat komunikasi yang sangat penting. Dengan berbahasa, seseorang dapat menyampaikan suatu ide, pikiran, perasaan maupun gagasan kepada orang lain (Asrif, 2019:11-12). Bahkan melalui bahasa, orang dapat menerima dan menyampaikan pengetahuan atau pengalamannya kepada orang lain, baik secara lisan maupun secara tertulis (Noermanzah, 2019:307).

Keterampilan berbahasa mencakup empat segi, yaitu keterampilan menyimak, berbicara, membaca, dan menulis (Zulaeha, 2013:98). Keempat keterampilan tersebut erat hubungannya dengan proses berpikir yang mendasari bahasa. Namun, dalam hal ini keterampilan menulis merupakan keterampilan berbahasa yang paling akhir dikuasai oleh pelajar bahasa setelah kemampuan mendengarkan, berbicara, dan membaca. Pada hakikatnya keterampilan menulis merupakan suatu keterampilan berbahasa yang digunakan untuk berkomunikasi secara tidak langsung dengan orang lain (Noermanzah dkk., 2018:116-117). Keterampilan menulis memerlukan kesungguhan untuk mengolah, menata, dan mempertimbangkan secara kritis gagasan yang akan dituangkan dalam bentuk tulisan (Tarigan dalam Awalludin, 2018:160). Dengan menulis, seseorang akan mampu mencatat, melaporkan, meyakinkan, memaparkan, bahkan mempengaruhi orang lain (Karto, 2019:2718).

Kegiatan menulis dapat dilakukan secara lisan dan tulisan. Surat-menyurat merupakan salah satu kegiatan bahasa yang dilakukan dengan interaksi tulis. Dalam kehidupan sehari-hari kita harus berurusan dengan namanya surat. Sejak zaman dahulu sampai sekarang, kehidupan manusia tidak terlepas dengan surat-menyurat. Menurut Awalludin (2017:215), surat merupakan sarana komunikasi tertulis untuk menyampaikan suatu tujuan kepada pihak lain. Tujuan yang disampaikan melalui surat dapat berupa permintaan, pernyataan, pertimbangan, lamaran, dan sebagainya. Selanjutnya, Rachman (2010:10) mengemukakan bahwa "surat merupakan media komunikasi yang berfungsi sebagai alat untuk berkomunkasi yang menggunakan bahasa tulisan yang ditulis di atas kertas". Berdasarkan pendapat para ahli dapat disimpulkan bahwa surat adalah tempat komunikasi yang bertujuan menyampaikan pesan atau informasi tentang suatu hal dalam bentuk keperluan kegiatan tertentu.

Kegiatan surat-menyurat dapat berlangsung jika terdapat tiga komponen yaitu penulis, pesan, dan pembaca surat (Djuharie \& Suherli, 2009). Supaya kegiatan dapat mencapai tujuan atau sasaran secara efektif, bahasa yang dapat digunakan harus dapat mengungkapkan pesan surat sesuai dengan sifat surat, kedudukan penulis, dan pembaca surat (Wiguno \& Jaja, 2019, 107-108). Dengan demikian, kegiatan surat-menyurat mempunyai peran sebagai alat berkomunikasi tertulis yang dirasakan semakin penting dalam kehidupan bermasyarakat pada saat ini. Demikian pula dengan instansi pemerintah, swasta, serta lembaga keorganisasian, kegiatan surat-menyurat merupakan suatu kegiatan keadministrasian yang penting. 
Salah satu surat yang sangat penting perannya dalam kegiatan suatu instansi atau lembaga pemerintahan dan swasta, yaitu surat dinas. Surat dinas merupakan surat yang berisi masalah-masalah kedinasan yang dikeluarkan oleh kantor atau pemerintah (Darma \& Kosasih, 2009:9). Dengan demikian, surat dapat membawa informasi kepada yang dituju oleh penulis surat dinas (Nadia \& Sugihastuti, 2018). Surat dinas yang dikeluarkan sebenarnya, memiliki fungsi untuk keperluan menyampaikan pemberitahuan suatu penugasan, izin, pengumuman, dan lainnya, kepada staff di suatu lembaga terkait. Surat dinas ini biasanya ditulis menggunakan bahasa baku dan formal, karena termasuk dalam kategori surat resmi (Nani, 2018:135). Surat dapat ditinjau dari sifat isinya, surat adalah jenis karangan paparan. Berbeda halnya jika ditinjau dari wujud penuturannya, surat merupakan percakapan tertulis dari seseorang kepada seseorang. Apabila ditinjau dari fungsinya, surat merupakan sarana komunikasi tertulis. Komunikasi tersebut dapat berupa pengumuman, pemberitahuan, keterangan, dan sebagainya.

Berdasarkan kurikulum 2013 di tingkat SMP, materi tentang surat dinas ada dalam silabus pembelajaran kelas VII semester II. Adapun penelitian ini akan difokuskan pada Kompetensi dasar 4.14 yaitu menulis surat (pribadi dan dinas), khususnya menulis surat dinas untuk kepentingan resmi dengan memperhatikan struktur teks, kebahasaan, dan isi.

Saat ini, kegiatan menulis surat sudah sangat jarang digunakan, karena kebanyakan orang termasuk siswa sudah memiliki gawai, sehingga siswa malas dan kurang menyenangi pembelajaran dan merasa bosan dalam menulis surat. Oleh karena itu, banyak siswa yang kurang mampu memahami tentang surat dinas dan kurang mampu juga saat praktik menulis surat dinas. Banyak siswa yang kurang tepat dalam penulisan dan penggunaan kata baku. Fitri (2016:120), menjelaskan tingkat kemampuan surat dinas dipengaruhi oleh pemahaman siswa terhadap sistematika dan isi dari setiap unsur yang ada dalam surat dinas. Untuk itu, penulis tertarik meneliti "Adakah hubungan pemahaman tentang surat menyurat terhadap kemampuan siswa kelas VII SMP Negeri 9 OKU dalam menulis surat dinas? Hal ini bermanfaat bagi guru bahasa Indonesia bahwa untuk meningkatkan kemampuan menulis surat dinas harus terlebih dahulu maksimalkan pemahaman tentang materi menulis surat dinas, mulai sistematika surat dinas dan isi dari setiap komponen surat dinas.

\section{METODE}

Penelitian ini mengunakan metode korelasi sebagai bagian dari penelitian expost facto. Tujuan penggunaan metode korelasi adalah untuk mengetahui tingkat hubungan pemahaman surat-menyurat terhadap kemampuan menulis surat dinas siswa kelas VII SMP Negeri 9 OKU. Populasi dalam penelitian ini adalah siswa kelas VII SMP Negeri 9 OKU dan sampel penelitian yaitu 29 siswa kelas VII SMP Negeri 9 OKU.

Variabel penelitian yaitu variabel $\mathrm{x}$ (variabel bebas/independent variabel) yaitu kemampuan pemahaman surat-menyurat dan variabel y (variabel terikat/dependent variabel) yaitu kemampuan menulis surat dinas. Teknik pengumpulan data menggunakan tekni tes. Jenis tes yang digunakan yaitu tes pilihan ganda tentang pemahaman tentang surat-menyurat dan tes uraian dalam menulis surat dinas. Hipotesis penelitian yaitu ada hubungan yang positif pemahaman surat-menyurat terhadap kemampuan menulis surat dinas siswa kelas VII SMP Negeri 9 OKU. 
Teknik analisis data dengan cara mengitung skor setiap kemampuan siswa dari nilai variabel $x$ dan $y$, menghitung nilai rata-rata variabel $x$, menghitung nilai rata-rata variabel $\mathrm{y}$, menghitung standar deviasi, uji normalitas, menghitung koefisien korelasi dengan Product Moment atau $r_{x y}$, menghitung nilai $t_{t a b e l}$, dan membandingkan nilai hasil perhitungan $r_{x y}$ dengan nilai $t_{\text {tabel }}$ dengan syarat apabila $r_{x y} \geq t_{\text {tabel }}$ maka memiliki hubungan yang positif antara variabel $x$ dengan variabel $y$.

\section{HASIL}

\section{Tes Pemahaman Surat-Menyurat}

Penganalisisan data tes pilihan ganda dilakukan dengan membandingkan jawaban siswa dengan kunci jawaban, kemudian menghitung nilai akhir siswa berdasarkan jumlah jawaban siswa yang sesuai dengan kunci jawaban berbanding jumlah skor keseluruhan dikali seratus atau

Nilai $=\frac{\text { Skor Mentah }}{\text { Skor Maksimal Ideal }} \times 100$

Adapun nilai tes pemahaman surat-menyurat yang diperoleh siswa berjumlah 29 orang dapat dilihat pada tabel berikut ini.

Tabel 1. Nilai Tes Pemahaman Surat-Menyurat

\begin{tabular}{|c|c|c|c|c|}
\hline No. & Inisial & Jawaban Benar & Nilai & Kategori Penilaian \\
\hline 1 & WAF & 14 & 70 & Mampu \\
\hline 2 & SO & 10 & 50 & Kurang Mampu \\
\hline 3 & SOZ & 12 & 60 & Cukup Mampu \\
\hline 4 & SA & 5 & 25 & Gagal \\
\hline 5 & SN & 6 & 30 & Gagal \\
\hline 6 & SU & 8 & 40 & Gagal \\
\hline 7 & RS & 8 & 40 & Gagal \\
\hline 8 & IL & 13 & 65 & Cukup Mampu \\
\hline 9 & IF & 15 & 75 & Mampu \\
\hline 10 & FF & 15 & 75 & Mampu \\
\hline 11 & FK & 10 & 50 & Kurang Mampu \\
\hline 12 & DJY & 15 & 75 & Mampu \\
\hline 13 & DAP & 13 & 65 & Cukup Mampu \\
\hline 14 & ADP & 13 & 65 & Cukup Mampu \\
\hline 15 & AAP & 12 & 60 & Cukup Mampu \\
\hline 16 & $A D$ & 16 & 80 & Sangat Mampu \\
\hline 17 & AK & 9 & 45 & Gagal \\
\hline 18 & ZZ & 8 & 40 & Gagal \\
\hline 19 & RA & 8 & 40 & Gagal \\
\hline 20 & RS & 9 & 45 & Gagal \\
\hline 21 & PAA & 9 & 45 & Gagal \\
\hline 22 & NAR & 12 & 60 & Cukup Mampu \\
\hline 23 & NP & 11 & 55 & Kurang Mampu \\
\hline 24 & $\mathrm{MZ}$ & 13 & 65 & Cukup Mampu \\
\hline 25 & $\mathrm{MBH}$ & 9 & 45 & Gagal \\
\hline 26 & $\mathrm{MH}$ & 11 & 55 & Kurang Mampu \\
\hline 27 & KDW & 18 & 90 & Sangat Mampu \\
\hline 28 & IP & 14 & 70 & Mampu \\
\hline 29 & IS & 13 & 65 & Cukup Mampu \\
\hline \multicolumn{3}{|c|}{ Jumlah } & \multicolumn{2}{|l|}{1645} \\
\hline \multicolumn{3}{|c|}{ Rata-rata } & \multicolumn{2}{|l|}{56,72} \\
\hline
\end{tabular}


Berdasarkan rincian tersebut, kategori nilai tes pilihan ganda siswa dapat dirincikan sebagai berikut.

Tabel 2. Analisis Distribusi Frekuensi dan

Presentase Nilai Pemahaman Surat-Menyurat

\begin{tabular}{llcll}
\hline No. & Skor Angka & Jumlah Siswa & Presentase $(\%)$ & Kategori \\
\hline 1 & $80-100$ & 2 & 6,89 & Sangat Mampu \\
\hline 2 & $66-79$ & 5 & 17,24 & Mampu \\
\hline 3 & $56-65$ & 8 & 27,59 & Cukup Mampu \\
\hline 4 & $46-55$ & 4 & 13,79 & Kurang Mampu \\
\hline 5 & $0-45$ & 10 & 34,49 & Gagal \\
\hline Jumlah & 29 & 100,00 & \\
\hline Rata-rata & & 56,72 & Cukup Mampu \\
\hline
\end{tabular}

Berdasarkan tabel tersebut dapat diketahui siswa yang memperoleh nilai 80100 sebanyak 2 orang $(6,89 \%)$ dengan kategori sangat mampu. Siswa yang memperoleh nilai $66-79$ sebanyak 5 orang $(17,24 \%)$ dengan kategori mampu. Siswa yang memperoleh nilai $56-65$ sebanyak 8 orang $(27,59 \%)$ dengan kategori cukup mampu. Siswa yang memperoleh nilai $46-55$ sebanyak 4 orang $(13,79 \%)$ dengan kategori kurang mampu. Siswa yang memperoleh nilai $<45$ sebanyak 10 orang $(34,49 \%)$ dengan kategori gagal. Dari data tersebut yang memperoleh nilai di atas KKM yaitu 70 berjumlah 7 siswa (24,14\%). Dengan demikian, dapat disimpulkan bahwa siswa SMP Negeri 9 OKU cukup mampu dalam pemahaman surat-menyurat.

\section{Tes Kemampuan Menulis Surat Dinas}

Tes menulis surat dinas dilaksanakan untuk mengetahui kemampuan siswa menulis surat dinas yang telah diberikan. Adapun tes yang dilakukan dengan cara memberikan tes esai mengenai surat dinas kemudian siswa diminta untuk menulis surat dinas sesuai petunjuk instrumen tes.

Berdasarkan penganalisisan data kemampuan siswa menulis surat dinas siswa kelas VII SMP Negeri 9 OKU, hasil tes yang diperoleh siswa dalam menulis surat dinas dapat dilihat pada tabel berikut ini.

Tabel 3. Hasil Tes Kemampuan Menulis Surat Dinas

\begin{tabular}{|c|c|c|c|c|c|c|c|c|c|c|}
\hline \multirow[b]{2}{*}{ No. } & \multirow[b]{2}{*}{ Inisial } & \multicolumn{6}{|c|}{ Aspek Penilaian Surat } & \multirow[b]{2}{*}{ Jumlah } & \multirow[b]{2}{*}{ Nilai } & \multirow[b]{2}{*}{ Keterangan } \\
\hline & & $\begin{array}{c}\text { Isi } \\
\text { Surat }\end{array}$ & $\begin{array}{l}\text { Unsur } \\
\text { Surat }\end{array}$ & $\begin{array}{c}\text { Format } \\
\text { Surat }\end{array}$ & Kata & kalimat & Ejaan & & & \\
\hline 1 & WAF & 2 & 2 & 2 & 2 & 2 & 2 & 12 & 60 & Cukup Mampu \\
\hline 2 & $\mathrm{SO}$ & 1 & 4 & 2 & 2 & 2 & 2 & 13 & 65 & Cukup Mampu \\
\hline 3 & $\mathrm{SOZ}$ & 1 & 1 & 1 & 1 & 1 & 1 & 6 & 30 & Gagal \\
\hline 4 & SA & 1 & 1 & 1 & 1 & 1 & 1 & 6 & 30 & Gagal \\
\hline 5 & SN & 1 & 1 & 4 & 1 & 1 & 1 & 9 & 45 & Gagal \\
\hline 6 & SU & 1 & 3 & 2 & 2 & 2 & 2 & 12 & 60 & Cukup Mampu \\
\hline 7 & RS & 1 & 1 & 1 & 1 & 1 & 1 & 6 & 30 & Gagal \\
\hline 8 & $\mathrm{IL}$ & 1 & 3 & 2 & 2 & 2 & 1 & 11 & 55 & Kurang Mampu \\
\hline 9 & IF & 3 & 2 & 1 & 2 & 1 & 1 & 10 & 50 & Kurang Mampu \\
\hline 10 & $\mathrm{FF}$ & 2 & 2 & 1 & 2 & 2 & 2 & 11 & 55 & Kurang Mampu \\
\hline 11 & FK & 1 & 4 & 2 & 2 & 1 & 1 & 11 & 55 & Kurang Mampu \\
\hline 12 & DJY & 2 & 4 & 2 & 2 & 1 & 1 & 12 & 60 & Cukup Mampu \\
\hline 13 & DAP & 1 & 2 & 2 & 1 & 1 & 1 & 8 & 40 & Gagal \\
\hline 14 & ADP & 2 & 2 & 4 & 2 & 2 & 2 & 14 & 70 & Mampu \\
\hline 15 & AAP & 2 & 1 & 1 & 2 & 2 & 2 & 10 & 50 & Kurang Mampu \\
\hline 16 & $A D$ & 1 & 3 & 3 & 2 & 2 & 2 & 13 & 65 & Cukup Mampu \\
\hline
\end{tabular}




\begin{tabular}{|c|c|c|c|c|c|c|c|c|c|c|}
\hline 17 & $\mathrm{AK}$ & 2 & 3 & 2 & 2 & 2 & 2 & 13 & 65 & Cukup Mampu \\
\hline 18 & $\mathrm{ZZ}$ & 3 & 3 & 2 & 2 & 2 & 2 & 14 & 70 & Mampu \\
\hline 19 & FA & 1 & 1 & 1 & 1 & 1 & 1 & 6 & 30 & Gagal \\
\hline 20 & RS & 3 & 3 & 3 & 2 & 2 & 2 & 15 & 75 & Mampu \\
\hline 21 & PAA & 2 & 2 & 2 & 2 & 2 & 2 & 12 & 60 & Cukup Mampu \\
\hline 22 & NAR & 3 & 3 & 2 & 2 & 1 & 1 & 12 & 60 & Cukup Mampu \\
\hline 23 & $\mathrm{MZ}$ & 3 & 3 & 2 & 2 & 2 & 2 & 14 & 70 & Mampu \\
\hline 24 & NP & 2 & 2 & 2 & 2 & 1 & 1 & 10 & 50 & Kurang Mampu \\
\hline 25 & $\mathrm{MBH}$ & 3 & 3 & 2 & 2 & 2 & 1 & 13 & 65 & Cukup Mampu \\
\hline 26 & $\mathrm{MH}$ & 1 & 2 & 2 & 1 & 1 & 1 & 8 & 40 & Gagal \\
\hline 27 & KDW & 2 & 3 & 2 & 2 & 2 & 2 & 13 & 65 & Cukup Mampu \\
\hline 28 & IP & 3 & 3 & 4 & 2 & 2 & 2 & 16 & 80 & Sangat Mampu \\
\hline 29 & IS & 3 & 3 & 3 & 2 & 2 & 2 & 15 & 75 & Mampu \\
\hline \multicolumn{2}{|c|}{$\begin{array}{l}\text { Jumlah } \\
\text { Rata-rata }\end{array}$} & 60 & 73 & 62 & 52 & 46 & 44 & 337 & 1625 & \\
\hline & & & & & & & & & $\begin{array}{l}56,7 \\
2 \\
\end{array}$ & \\
\hline
\end{tabular}

Berdasarkan rincian data tersebut, kategori nilai tes menulis surat dinas siswa sebagai berikut.

Tabel 4. Analisis Distribusi Frekuensi dan Persentase Nilai Kemampuan Menulis Surat Dinas

\begin{tabular}{cllll}
\hline No. & Skor Angka & Jumlah Siswa & Presentase (\%) & Kategori \\
\hline 1 & $80-100$ & 1 & 3,44 & Sangat Mampu \\
\hline 2 & $66-79$ & 4 & 13,80 & Mampu \\
\hline 3 & $56-65$ & 11 & 37,93 & Cukup Mampu \\
\hline 4 & $46-55$ & 6 & 20,69 & Kurang Mampu \\
\hline 5 & $0-45$ & 7 & 24,14 & Gagal \\
\hline Jumlah & 29 & 100,00 & \\
\hline Rata-rata & & 56,03 & Cukup Mampu \\
\hline
\end{tabular}

Berdasarkan tabel di atas dapat diketahui siswa memperoleh nilai 80-100 sebanyak 1 orang $(3,44 \%)$ dengan kategori sangat mampu. Siswa yang memperoleh nilai $66-79$ sebanyak 4 orang $(13,80 \%)$ dengan kategori mampu. Siswa yang memperoleh nilai 56-65 sebanyak 11 orang $(37,93 \%)$ dengan kategori cukup mampu. Siswa yang memperoleh nilai $46-55$ sebanyak 6 orang $(20,69 \%)$ dengan kategori kurang mampu. Siswa yang memperoleh nilai < 45 sebanyak 7 orang $(24,14 \%)$ dengan kategori gagal. Berdasarkan data tersebut siswa yang memperoleh nilai di atas KKM yaitu 70 berjumlah 5 orang $(17,24 \%)$. Dengan demikian, dapat disimpulkan bahwa siswa SMP Negeri 9 OKU cukup mampu dalam menulis surat dinas.

\section{Hasil Korelasi antara Pemahaman tentang Surat-Menyurat dan Kemampuan Menulis Surat Dinas}

Menentukan korelasi antara pemahaman surat-menyurat dan menulis surat dinas maka kedua nilai dimasukkan ke dalam tabel. Nilai pemahaman suratmenyurat adalah variabel $X$ sedangkan nilai kemampuan menulis surat dinas adalah variabel $\mathrm{Y}$. Berdasarkan hasil analisis kedua tes yang dilakukan diperoleh data sebagai berikut. 
Hubungan Pemahaman tentang Surat-Menyurat terhadap Kemampuan Menulis Surat Dinas Siswa Kelas VII SMP Negeri 9 Oku

Tabel 5. Hasil Analisis Korelasional

\begin{tabular}{cllllll}
\hline No. & Inisial & $\mathrm{X}$ & $\mathrm{Y}$ & $\mathrm{X} . \mathrm{Y}$ & \multicolumn{1}{c}{$\mathrm{X}^{2}$} & $\mathrm{Y}^{2}$ \\
\hline 1 & WAF & 70 & 60 & 4200 & 4900 & 3600 \\
\hline 2 & SO & 50 & 65 & 3250 & 2500 & 4225 \\
\hline 3 & SOZ & 60 & 30 & 1800 & 3600 & 900 \\
\hline 4 & SA & 25 & 30 & 750 & 625 & 900 \\
\hline 5 & SN & 30 & 45 & 1350 & 900 & 2025 \\
\hline 6 & SU & 40 & 60 & 2400 & 1600 & 3600 \\
\hline 7 & RS & 40 & 30 & 1200 & 1600 & 900 \\
\hline 8 & IL & 65 & 55 & 3575 & 4225 & 3025 \\
\hline 9 & IF & 75 & 50 & 3750 & 5625 & 2500 \\
\hline 10 & FF & 75 & 55 & 4125 & 5625 & 3025 \\
\hline 11 & FK & 50 & 55 & 2750 & 2500 & 3025 \\
\hline 12 & DJY & 75 & 60 & 4500 & 5625 & 3600 \\
\hline 13 & DAP & 65 & 40 & 2600 & 4225 & 1600 \\
\hline 14 & ADP & 65 & 70 & 4550 & 4225 & 4900 \\
\hline 15 & AAP & 60 & 50 & 3000 & 3600 & 2500 \\
\hline 16 & AD & 80 & 65 & 5200 & 6400 & 4225 \\
\hline 17 & AK & 45 & 65 & 2925 & 2025 & 4225 \\
\hline 18 & ZZ & 40 & 70 & 2800 & 1600 & 4900 \\
\hline 19 & FA & 40 & 30 & 1200 & 1600 & 900 \\
\hline 20 & RS & 45 & 75 & 3375 & 2025 & 5625 \\
\hline 21 & PAA & 45 & 60 & 2700 & 2025 & 3600 \\
\hline 22 & NAR & 60 & 60 & 3600 & 3600 & 3600 \\
\hline 23 & MZ & 55 & 70 & 3850 & 3025 & 4900 \\
\hline 24 & NP & 65 & 50 & 3250 & 4225 & 2500 \\
\hline 25 & MBH & 45 & 65 & 2925 & 2025 & 4225 \\
\hline 26 & MH & 55 & 40 & 2200 & 3025 & 1600 \\
\hline 27 & KDW & 90 & 65 & 5850 & 8100 & 4225 \\
\hline 28 & IP & 70 & 80 & 5600 & 4900 & 6400 \\
\hline 29 & IS & 65 & 75 & 4875 & 4225 & 5625 \\
\hline Jumlah & 1645 & 1625 & 94150 & 100175 & 96875 \\
\hline & & & & & &
\end{tabular}

Jadi, dari perhitungan korelasi dengan menggunakan Product Moment di atas dapat diketahui $r_{x y}=0,987$. Jika diinterprestasikan pada kriteria yang dikutip dari Hasan maka dapat disimpulkan bahwa antara variabel $x$ dan variabel $y$, termasuk korelasi positif tinggi.

Jika diinterpretasikan dengan $r$ tabel maka dicari terlebih dahulu derajat bebasnya (db) atau degree off freedom (df).

$$
\begin{aligned}
\mathrm{df} & =\mathrm{N}-\mathrm{nr} \\
& =29-2 \\
& =27
\end{aligned}
$$

Dengan db sebesar 27, diperoleh $r$ "Product Moment" pada taraf signifikan 5\% $=0,381$, jika kita bandingkan dengan $r$ hitung $\left(r_{x y}\right)$, maka $r_{x y}>r$ Product Moment. Dengan demikian, Ha diterima dan Ho ditolak. Jadi dapat disimpulkan ada hubungan yang signifikan pada taraf yang tinggi atau kuat antara pemahaman surat-menyurat dengan kemampuan menulis surat dinas siswa kelas VII SMP Negeri 9 OKU. 


\section{PEMBAHASAN}

Hasil penelitian menunjukkan ada hubungan yang positif antara pemahaman surat-menyurat dengan kemampuan menulis surat dinas siswa kelas VII SMP Negeri 9 OKU. Artinya, semakin baik pemahaman materi tentang surat dinas siswa maka akan semakin baik kemampuan menulis surat dinasnya. Hal ini sesuai dengan pendapat Fitri (2016:120) bahwa tingkat kemampuan surat dinas dipengaruhi oleh pemahaman siswa terhadap sistematika dan isi dari setiap unsur yang ada dalam surat dinas.

Berdasarkan hasil tes pemahaman surat-menyurat siswa kelas VII SMP Negeri 9 OKU dapat diketahui bahwa siswa yang memperoleh nilai 80-100 sebanyak 2 orang $(6,89 \%)$ dengan kategori sangat mampu. Siswa yang memperoleh nilai $66-79$ sebanyak 5 orang $(17,24 \%)$ dengan kategori mampu. Siswa yang memperoleh nilai 56 -65 sebanyak 8 orang $(27,59 \%)$ dengan kategori cukup mampu. Siswa yang memperoleh nilai $46-55$ sebanyak 4 orang $(13,79 \%)$ dengan kategori kurang mampu. Siswa yang memperoleh nilai < 45 sebanyak 10 orang $(34,49 \%)$ dengan kategori gagal. Secara keseluruhan, kemampuan siswa dalam memahami surat-menyurat termasuk kategori cukup mampu. Hal ini ditunjukkan dari nilai rata-rata kelas yang diperoleh siswa yaitu 56,72. Secara lengkap hasil tes pemahaman tentang surat-menyurat seperti pada grafik berikut.

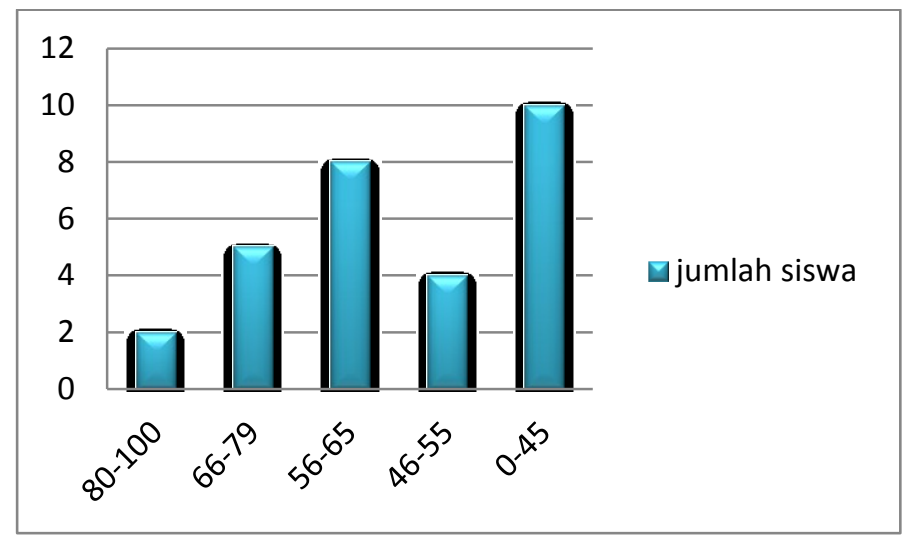

Grafik 1. Nilai Pemahaman Surat-Menyurat

Kemudian, dari analisis tes menulis surat dinas dapat diketahui siswa memperoleh nilai 80-100 sebanyak 1 orang atau 3,44\% dengan kategori sangat mampu. Siswa yang memperoleh nilai $66-79$ sebanyak 4 orang atau $13,80 \%$ dengan kategori mampu. Siswa yang memperoleh nilai 56-65 sebanyak 11 orang atau $37,93 \%$ dengan kategori cukup mampu. Siswa yang memperoleh nilai $46-55$ sebanyak 6 orang atau 20,69\% dengan kategori kurang mampu. Siswa yang memperoleh nilai < 45 sebanyak 7 orang atau $24,14 \%$ dengan kategori gagal. Secara keseluruhan kemampuan siswa dalam menulis surat dinas termasuk kategori cukup mampu. Hal ini ditunjukkan dari nilai rata-rata kelas yang diperoleh siswa yaitu 56,03 . berikut.

Secara lengkap hasil kemampuan menulis surat dinas seperti pada grafik 


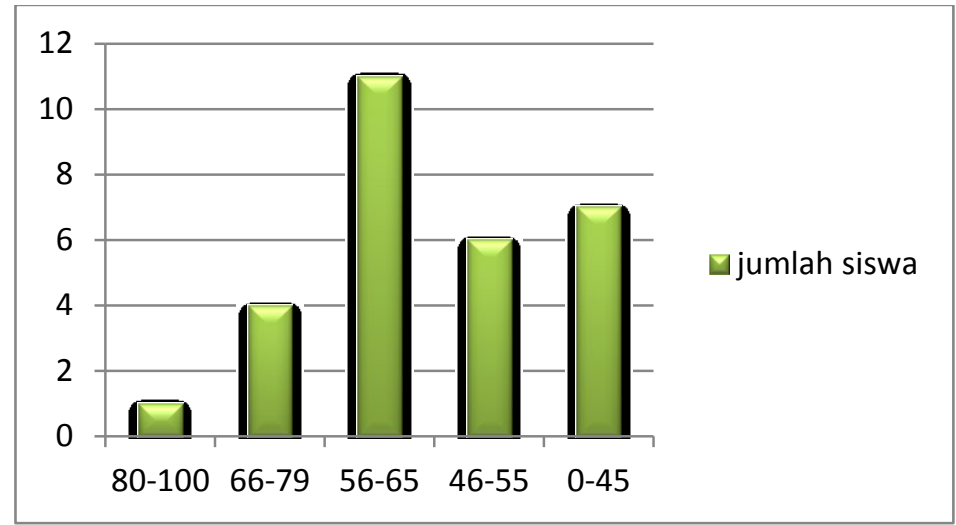

Grafik 2. Nilai Kemampuan Menulis Surat Dinas

Berdasarkan hasil pemahaman surat-menyurat dan kemampuan menulis surat dinas, dapat dilihat pada indikator kemampuan menulis surat dinas berikut ini.

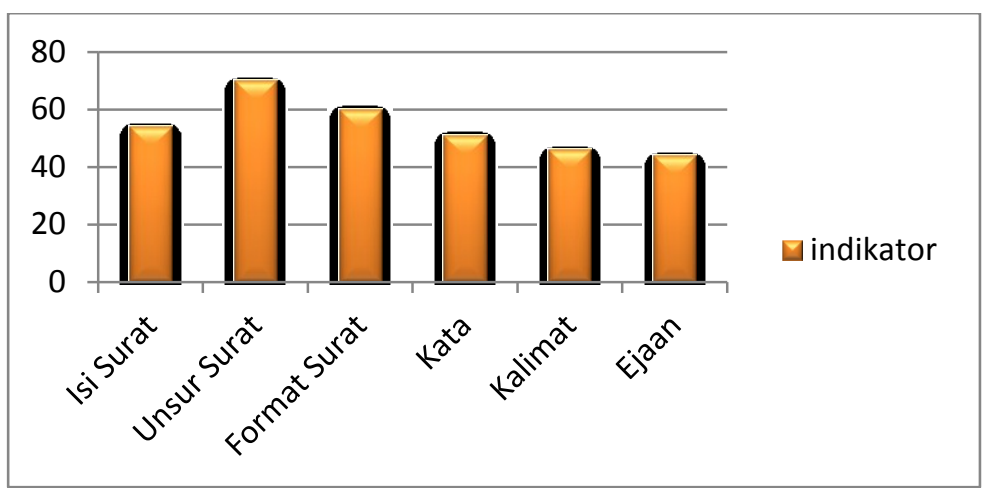

Grafik 3. Indikator Kemampuan Menulis Surat Dinas

Berdasarkan indikator kemampuan menulis surat dinas secara keseluruhan kemampuan siswa dalam kategori cukup mampu, tetapi pada kemampuan menulis isi surat secara keseluruhan siswa dinilai kurang. Hal tersebut disebabkan oleh kurang mampunya siswa dalam mengaitkan maksud surat secara keseluruhan. Contohnya "memberitahukan dalam rangka" seharusnya ditulis "memberitahukan bahwa dalam rangka". Dari sisi unsur surat, siswa kurang mampu dalam penulisan tanggal surat, salam pembuka, dan salam penutup. Selanjutnya, dari sisi bentuk surat, siswa masih bingung susunan atau letak dan bagian-bagian surat dinas sesuai dengan bentuk surat dinas lurus penuh. Dari sisi kata atau diksi, pemilihan kata yang ditulis kurang sesuai dengan konteks surat dinas. Dari sisi ejaan, siswa cukup mampu dalam penempatan tanda baca titik, tanda koma, tanda titik koma, dan huruf kapital.

Selanjutnya, hasil tes yang diberikan dalam bentuk menjawab soal pilihan ganda berupa menulis surat dinas, siswa dapat menulis dengan kategori cukup mampu. Walau demikian, ada baiknya hasil yang telah dicapai lebih ditingkatkan lagi. Oleh karena itu, dalam pelaksanaan pembelajaran bahasa Indonesia seorang guru diharapkan mampu menumbuhkembangkan keterampilan bahasa, tidak terkecuali 
dalam hal kemampuan menulis surat dinas. Dengan keterampilan tersebut, sehingga siswa diharapkan tidak mengalami kesulitan dalam belajar tentang menulis surat khususnya surat dinas.

Kegiatan pembelajaran menulis surat dinas menjadi aktif dan kreatif karena siswa diberikan pengetahuan dan wawasan yang sesuai dengan bagaimana menulis surat yang baik dan benar. Dalam kegiatan ini tidak serta merta siswa langsung melakukannya, ada beberapa siswa yang pada awalnya agak sulit menulis surat dinas karena belum begitu memahami tentang bagaimana cara menulis surat dengan baik. Pada awalnya dalam praktik menulis surat dinas siswa kelas VII belum dilakukan secara maksimal, hanya sebatas teori yang dipelajari. Walaupun demikian, dengan bimbingan dan pengarahan serta latihan yang terus-menerus yang diberikan guru, sehingga siswa lebih dapat memahami dan bisa menerapkannya dalam pembelajaran menulis surat dinas.

Berdasarkan hasil penelitian dan perhitungan korelasi dengan menggunakan rumus product moment diketahui bahwa besarnya koefisien korelasi antara pemahaman surat-menyurat dengan kemampuan menulis surat dinas terdapat hubungan yang positif dengan interpretasi yang tinggi. Hal tersebut dibuktikan dengan nilai $r$ hitung $\left(r_{x y}\right)=0,987$. Selanjutnya nilai $r_{x y}=0,987$ dibandingkan dengan nilai $r$ tabel untuk taraf signifikan $5 \%=0,381$. Bila dibandingkan antara $r_{x y}$ dengan $r$ tabel, maka nilai $r_{x y}$ pada taraf signifikan $5 \%$ lebih besar dari $r$ tabel. Hasil penelitian tersebut membuktikan bahwa pada taraf signifikan $5 \%$ hipotesis nihil $(\mathrm{Ho})$ ditolak, sedangkan hipotesis alternatif $(\mathrm{Ha})$ diterima atau disetujui, berarti terdapat hubungan yang positif antara pemahaman surat-menyurat dan kemampuan menulis surat dinas.

Berdasarkan deskripsi dan analisis data, dapat diketahui bahwa terdapat hubungan yang positif antara pengetahuan tentang surat-menyurat dengan kemampuan menulis surat dinas siswa pada tingkat korelasi yang tinggi atau kuat. Hal tersebut berarti pemahaman surat-menyurat memiliki pengaruh terhadap kemampuan menulis surat dinas. Untuk mencapai hasil yang baik, peserta didik harus lebih banyak belajar dan mempraktikkannya agar lebih memahami dan mengerti cara menulis surat dengan baik dan benar.

\section{KESIMPULAN DAN SARAN}

Berdasarkan hasil penelitian menunjukkan bahwa ada hubungan yang signifikan antara pemahaman surat-menyurat dengan kemampuan menulis surat dinas siswa kelas VII SMP Negeri 9 OKU. Hal ini dibuktikan dengan perhitungan korelasi antara data tes pemahaman surat-menyurat dan kemampuan menulis surat dinas siswa kelas VII SMP Negeri 9 OKU diperoleh nilai "r" product moment dengan df sebesar 27 diperoleh " $r$ " product moment pada taraf signifikan $5 \%=0,381$ dengan $\mathrm{r}_{\mathrm{xy}}=0,987$. Jika dibandingkan dengan $\mathrm{r}$ hitung $\left(\mathrm{r}_{\mathrm{xy}}\right)$, maka $\mathrm{r}_{\mathrm{xy}}>\mathrm{r}$ product moment. Artinya, hipotesis alternatif $(\mathrm{Ha})$ diterima dan hipotesis nihil $(\mathrm{Ho})$ ditolak.

Berdasarkan simpulan tersebut peneliti memberikan saran sebagai berikut.

1. Guru bahasa Indonesia agar dapat memotivasi siswa untuk lebih meningkatkan pemahaman dan kemampuan dalam menulis surat dinas dengan strategi-strategi pembelajaran yang menarik minat siswa.

2. Siswa, agar terus meningkatkan pemahaman khususnya dalam surat-menyurat sehingga dapat menambah keterampilan dalam menulis surat dinas. 
3. Peneliti lain, agar dapat dijadikan acuan untuk melakukan penelitian serupa dengan objek lain.

\section{DAFTAR PUSTAKA}

Arikunto, S. (2013). Prosedur Penelitian Suatu Pendekatan Praktik. Jakarta: Rineka Cipta.

Asrif, N. (2019). Pembinaan dan Pengembangan Bahasa Daerah dalam Memantapkan Kedudukan dan Fungsi Bahasa Indonesia. MABASAN, 4(1), 11-12. doi:10.26499/mab.v4i1.183

Awalludin, A. (2018). Efektivitas Model Decision Making dalam Pembelajaran Menulis Paragraf Persuasif Siswa Kelas X SMK Trisakti Baturaja. Jurnal Bindo Sastra, 2(1), 160. doi:10.32502/jbs.v2i1.923

Awalludin. (2017). Pengantar Bahasa Indonesia untuk Perguruan Tinggi. Yogyakarta: Deepublish.

Darma, Y. A. \& Kosasih, E. (2009). Menulis Surat Dinas Lengkap. Bandung: Yrama Widya.

Djuharie, O. S. \& Suherli. (2009). Surat Menyurat Serbaguna: Panduan Korespondensi Bahasa Indonesia. Bandung: Yrama Widya.

Fitri, R. (2016). Penerapan Teknik Pemodelan untuk Meningkatkan Kemampuan Menulis Surat Resmi Siswa Kelas VIII SMP. Gramatika STKIP PGRI Sumatera Barat, 2(1). 120, doi:10.22202/jg.2016.v2i2.1200

Karto, Suhartono, Susetyo, Noermanzah, Maisarah, I. (2019). The Differences Ability in Writing Descriptive Texts by Using Chain Writing and Conventional Methods. International Journal of Scientific \& Technology Research, 8(10), 2718. http://www.ijstr.org/paper-references.php?ref=IJSTR-1019-24157

Nadia, F. \& Sugihastuti. (2018). Surat Dinas: Teori dan Praktik. Yogyakarta: Pustaka Pelajar.

Nani, N. (2018). Analisis Kesalahan Berbahasa dalam Pembelajaran Menulis Surat Dinas pada Siswa Kelas VII G di SMP Negeri 17 Kota Serang. Jurnal Membaca (Bahasa dan Sastra Indonesia), 3(2), 135. doi:10.30870/jmbsi.v3i2.5227

Noermanzah, N. (2019). Bahasa sebagai Alat Komunikasi, Citra Pikiran, dan Kepribadian. Seminar Nasional Pendidikan Bahasa dan Sastra, Prosiding Seminar Nasional Bulan Bahasa (Semiba), 307, https://ejournal.unib.ac.id/index.php/semiba/article/view/11151/5537 
Noermanzah, N., Abid, S., \& Septaria, S. (2018). Improving the Ability of Writing a Narrative Charge by Using Animated Images Media Student Class V.B SD Negeri 17 Lubuklinggau. BAHTERA : Jurnal Pendidikan Bahasa dan Sastra, 17(2), 116. doi:10.21009/bahtera.172.9

Rachman, A. (2010). Menulis Surat. Bekasi: Adhi Aksara Abadi Indonesia.

Wiguno, P. S., \& Jaja, J. (2019). Pengembangan Bahan Ajar Teks Surat Berdasarkan Surat Pribadi dan Surat Dinas dan Implementasinya dalam Pembelajaran di SMP. Jurnal Tuturan, 8(2). 107-108, doi:10.33603/jt.v8i2.2868

Zulaeha, I. (2013). Pengembangan Model Pembelajaran Keterampilan Berbahasa Indonesia Berkonteks Multikultural. Litera, 12(1), 98, doi:10.21831/Itr.v12i01.1331 